\title{
Influence Of Subsidized Connection and Prepaid Metering On Successful Implementation of Slum Electrification Projects in Kenya: A Survey of Kaptembwa Slum in Nakuru County
}

\author{
Irene Wamaitha Kinyua, Dr Daniel Wanyoike
}

\begin{abstract}
Slum electrification in Kenya has always been faced by diverse challenges across the country. These challenges includes, the apathy to pay electricity connection fees, customers billing due to security issues and illegal tapping of electricity from Kenya Power and Lighting Company (KPLC) low voltage lines. KPLC has instituted various interventions to confront these challenges. This study sought to examine the influence of the above interventions on successful implementation of slum electrification. The target population for this study comprises connected residents of Kaptebwa slum. A simple random sampling was used with a sample size of 98.The descriptive and inferential statistics.The Pearson correlation matrix was used to examine the correlation between subsidized connection fee and slum electrification. The results indicated that there was a moderately strong correlation between subsidized connection fee and slum electrification of $r(84)=0.579, p<$ 0.01 . There was a weak correlation between pre paid metering and slum electrification of $r(84)=0.499, p<$ 0.0 .
\end{abstract}

\section{Introduction}

Slums exist in almost every country and have become a global phenomenon. A slum is an area that is characterized by poor structural quality of housing, overcrowding, insecure residential status, inadequate access to safe water and inadequate access to electricity and other infrastructure (Bystedt, 2011). Poor communities in and around cities globally are growing rapidly in developing countries, in many cases without any corresponding expansion in national services. The proportion of urban population living in slums was highest in Sub-Saharan Africa (61.7\%).

Approximately $35 \%$ of Kenya's population lives in urban areas and more than half of urban residents are living in slums. It is expected that the percentage of the population living in urban areas will increase by $50 \%$ by 2017, and as a result, the nation is facing the pressure of increased urbanization(Wafula, 2012). Electrification in the slum areas has been a challenge and According to KPLC (2010), about 50\% of the urban population in Kenya was electrified.

As part of trying to solve the problem, the Kenya Power was financed through the Kenya Electricity Expansion Project- AF, by the World Bank Group through the International Development Association (IDA) and the Global Partnership for Output Based Aid (GPOBA) that aimed to support the Government's initiatives of ensuring increased electricity access to Kenyans, particularly among low income groups in informal settlement areas(Saliku, 2015). The existing and new distribution transformers were to be optimized through extension of the low and medium voltage network to reach households located in the vicinity of these transformers(Cheseto, 2013). Besides, the Kenya power has subsidized the payments and improved flexibility as well as introduction of new power designs using small transformers, adjusted height of transformers and positioning lower voltage lines below.

\section{Problem Statement}

Electricity connection is key in the basic survival and supporting economic development in slum areas. It is also projected that over half of the world population will be living in urban areas by the year 2030. The urban poor mainly reside in slums, however due to their economic ability, slum dwellers have been unable to afford the cost of infrastructure like meters, wires or even pay their electricity bills in a consistent manner, as required. As a result, illegal electricity connections have thrived significantly and have been the key challenge in distribution of electricity in slim areas. Illegal connections not only cause huge losses to power distribution companies, but also pose huge safety dangers to the slum dwellers. In Nakuru Town, Kaptembwa is the largest slum with a population of over 79,480 (Nakuru CIDP, 2013). The problem of illegal connections has been wide spread in slums forcing the Kenya power company to pursue alternative strategies for safer and secure electricity connections in a partnership program between KPC and World Bank through Global Partnership on Output Based Aid (GPOBA) with an aim of connecting over 150,000 slum dwellers.

KPLC instituted diverse measures to confront those challenges. The measures included substituting timber poles to concrete poles, which cannot be easily climbed, constructing low voltage lines above the high 
voltage lines stopping low voltage line accessibility by illegal connectors and using small transformers on several poles to step down the voltage to distribution levels for a small number of households. Other measures included, using pre-paid meters, where the garget was installed on the pole instead of the house structure. In plight of the high cost of the electricity connection fee have been subsidized to Ksh 1, 160 with flexible repayment. However, there are no studies carried yet to determine how these initiatives have enhanced electrification in the slums.

\section{Research Objectives}

1. To establish the influence of subsidized connection fees on successful implementation of slum electrification

2. To establish the influence of pre-paid metering on successful implementation of slum electrification

\section{Literature Review}

The term connection fee is used to denote the amount charged to a consumer to connect to an established distribution network(Scott, 2014). The cost related to connection charge usually covers the estimated costs of materials, labor, and transport needed to make the connection from the nearest pole of the distribution system and along with the costs of inspection of the consumer's premises (Kristiansen, 2015).

The distribution of electricity whether for social or productive uses is a capital-intensive enterprise, and the cost of providing household connection to electricity services can be quite high (Njoroge, 2015). When connection charges are recovered through one-time, up-front fees for new customers, they can constitute a powerful disincentive to people who wish to obtain electricity, no matter how much they might desire the service (Kristiansen, 2015). High electricity connection prices can discourage low-income households that may be able to afford the monthly bills. Ethiopia has connected about 60,000 poor households under the World Bank-funded Electricity Access Rural Expansion Project, GPOBA (Scott, 2014).

According to Saibu (2016), prepayment system refers to the outlay made by a consumer for using a good or service before consumption.

\section{Research Design}

\section{Methodology}

This study utilized the descriptive research design. The descriptive study examines the study phenomenon by addressing who, what, when, where, and how questions.

\section{Study Population}

The target population for this study was the slum residents who were connected with electricity within Kaptembwa slums in Nakuru County. According KPLC central rift connectivity report the company connected 5,460 customers at Kaptembwa slums.

\section{Sample and sampling Technique}

Simple random sampling without replacement was adopted for this study. Since the entire population is large the research determined the sample size by using a formula by (Nassiuma, 2002). This formula is convenient for large sample sizes. The formula states that:

$\mathrm{n}=\left(\mathrm{Nc}_{\mathrm{v}}{ }^{2}\right) /\left(\mathrm{c}_{\mathrm{v}}{ }^{2}+(\mathrm{N}-1) \mathrm{e}^{2}\right)$

Where:

$\mathrm{n}=$ Sample size

$\mathrm{N}=$ Population

$\mathrm{C}_{\mathrm{v}}=$ Coefficient of variation (take 0.5 )

$\mathrm{e}=$ Tolerance at desired level of confidence, take 0.05 at $95 \%$ confidence level

Upon substitution, the sample size would be as follows:

$\mathrm{n}=\left(5460 * 0.5^{2}\right) /\left(0.5^{2}+(5460-1) * 0.05^{2}\right)$

$\mathrm{n}=98$ respondents.

\section{Data Collection Instrument}

The questionnaire was used as the data collection instrument.. The reliability of the questionnaire was tested using Cronbach's alpha which indicates the extent to which a set of test items can be treated to be measuring a single latent variable(Kombo \& Tromp, 2009).

\section{Data Processing and Analysis}

The data analysis was undertaken using SPSS for the analysis of the descriptive and inferential statistics. The descriptive statistics included the means, standard deviations and frequency distributions. 
Findings

Relationship between Subsidized Connection Fee and Slum Electrification

Table 1: Frequency Distribution of Subsidized Connection Fee

\begin{tabular}{|c|c|c|c|c|c|}
\hline $\begin{array}{l}\text { The subsided connection fee have impacted on slum } \\
\text { electrification in the following ways; }\end{array}$ & $\begin{array}{l}\text { SA } \\
\text { Freq. } \\
(\%)\end{array}$ & $\begin{array}{l}\text { A } \\
\text { Freq. } \\
(\%)\end{array}$ & $\begin{array}{l}\text { U } \\
\text { Freq. } \\
(\%)\end{array}$ & $\begin{array}{l}\text { D } \\
\text { Freq. } \\
(\%)\end{array}$ & $\begin{array}{l}\text { SD } \\
\text { Freq. } \\
(\%)\end{array}$ \\
\hline The connection fee is easily affordable & $\begin{array}{l}15 \\
(17.9 \%)\end{array}$ & $\begin{array}{l}38 \\
(45.2 \%)\end{array}$ & $\begin{array}{l}18 \\
(21.4 \%)\end{array}$ & $\begin{array}{l}13 \\
(15.5 \%)\end{array}$ & $\begin{array}{l}0 \\
(0 \%)\end{array}$ \\
\hline The level of connections in slum has greatly increased & $\begin{array}{l}34 \\
(40.5 \%)\end{array}$ & $\begin{array}{l}27 \\
(32.1)\end{array}$ & $\begin{array}{l}17 \\
(20.2 \%)\end{array}$ & $\begin{array}{l}6 \\
(7.1 \%)\end{array}$ & $\begin{array}{l}0 \\
(0 \%)\end{array}$ \\
\hline Has Enabled to reduced meter sharing & $\begin{array}{l}21 \\
(25.0 \%)\end{array}$ & $\begin{array}{l}32 \\
(38.1 \%)\end{array}$ & $\begin{array}{l}21 \\
(25.0 \%)\end{array}$ & $\begin{array}{l}10 \\
(11.9 \%)\end{array}$ & $\begin{array}{l}0 \\
(0 \%)\end{array}$ \\
\hline Small businessmen can now afford connection fee & $\begin{array}{l}12 \\
(14.3 \%)\end{array}$ & $\begin{array}{l}49 \\
(58.3 \%) \\
\end{array}$ & $\begin{array}{l}14 \\
(16.7 \%)\end{array}$ & $\begin{array}{l}9 \\
(10.7 \%)\end{array}$ & $\begin{array}{l}0 \\
(0 \%)\end{array}$ \\
\hline Equitable distribution of electric power in slums & $\begin{array}{l}27 \\
(32.1 \%)\end{array}$ & $\begin{array}{l}31 \\
(36.9 \%)\end{array}$ & $\begin{array}{l}22 \\
(26.2 \%)\end{array}$ & $\begin{array}{l}4 \\
(4.8 \%)\end{array}$ & $\begin{array}{l}0 \\
(0 \%)\end{array}$ \\
\hline
\end{tabular}

Table 1 shows the analysis of the data with regards to subsidised connection. As shown on the table a total of 53\% respondent were in agreement that the connection fee was easily affordable while $18 \%$ were uncertain and the lest disagreed. On the other hand, $62 \%$ of the sample responses were in agreement that subsidized connection fee and slum electrification increased level of connections in the slum. $20.2 \%$ of the respondents were uncertain while $39.1 \%$ of the respondents disagreed. More respondents, $63.1 \%$ agreed that the level of meter sharing had gone down as compared to respondents who disagreed at $11.9 \%$ while $25 \%$ were uncertain. Most of the respondents $69.0 \%$ agreed that there was equitable distribution of power, $19 \%$ were uncertain and $11.9 \% .72 .6 \%$ of them agreed that the can now afford connection fee while 10.7 disagreed

Table 2: Means and Standard Deviation of Subsidized Connection Fee

\begin{tabular}{|l|l|l|l|l|}
\hline & Min & Max & Mean & Std. Dev. \\
\hline The connection fee is easily affordable & 2 & 5 & 3.65 & 0.95 \\
\hline The level of connections in slum has greatly increased & 2 & 5 & 4.06 & 0.95 \\
\hline The level of illegal connections has gone down & 2 & 5 & 3.76 & 0.96 \\
\hline Equitable distribution of electric power in slums & 2 & 5 & 3.89 & 0.99 \\
\hline Small businessmen can now afford connection fee & 2 & 5 & 3.76 & 0.83 \\
\hline Equitable distribution of electric power in slums & 2 & 5 & 3.96 & 0.88 \\
\hline
\end{tabular}

To further gain an understanding on the influence of the subsidized connection fee on the success of slum electrification, the means and standard deviations were calculated on the 4.6. These means indicated that the respondents on average tended to agree that the respective metrics led to the success of the slum electrification at Kaptembwa slums in Nakuru. This is because they had means of between 3.5 and 4.5 while the standard deviations were $0.95,0.95,0.96,0.99,0.83$ and 0.88 respectively which meant that the responses were moderately distributed.

\section{Relationship between Pre-Paid Meter and Slum Electrification}

Table 3: Frequency Distributions of Pre Paid Meters on Slum Electrification

\begin{tabular}{|c|c|c|c|c|c|}
\hline $\begin{array}{l}\text { The prepaid meters have impacted on slum electrification } \\
\text { in the following ways; }\end{array}$ & $\begin{array}{l}\text { SA Freq. } \\
(\%)\end{array}$ & $\begin{array}{l}\text { A Freq. } \\
(\%)\end{array}$ & $\begin{array}{l}\text { U Freq. } \\
(\%)\end{array}$ & $\begin{array}{l}\text { D Freq. } \\
(\%)\end{array}$ & $\begin{array}{l}\text { SD Freq. } \\
(\%)\end{array}$ \\
\hline Easy monitoring of the no number of power units bought & $\begin{array}{l}21 \\
(25.0 \%)\end{array}$ & $\begin{array}{l}35 \\
(41.7 \%)\end{array}$ & $\begin{array}{l}17 \\
(20.2 \%)\end{array}$ & $\begin{array}{l}10 \\
(11.9 \%)\end{array}$ & $\begin{array}{l}1 \\
(1.2 \%)\end{array}$ \\
\hline $\begin{array}{l}\text { Has enabled me to control electricity consumption } \\
\text { according to my financial status }\end{array}$ & $\begin{array}{l}35 \\
(41.7 \%)\end{array}$ & $\begin{array}{l}26 \\
(31.0 \%)\end{array}$ & $\begin{array}{l}17 \\
(20.2 \%)\end{array}$ & $\begin{array}{l}5 \\
(6.0 \%)\end{array}$ & $\begin{array}{l}1 \\
(1.2 \%)\end{array}$ \\
\hline Reduced interruptions of KPLC employees in the premises & $\begin{array}{l}26 \\
(31.0 \%)\end{array}$ & $\begin{array}{l}28 \\
(33.3 \%)\end{array}$ & $\begin{array}{l}21 \\
(25.0 \%)\end{array}$ & $\begin{array}{l}9 \\
(27.0 \%)\end{array}$ & $\begin{array}{l}0 \\
(0.0 \%)\end{array}$ \\
\hline Reduced frequent complains to KPLC offices & $\begin{array}{l}36 \\
(42.9 \%)\end{array}$ & $\begin{array}{l}24 \\
(28.6 \%)\end{array}$ & $\begin{array}{l}1 \\
(1.2 \%)\end{array}$ & $\begin{array}{l}2 \\
(2.4 \%)\end{array}$ & $\begin{array}{l}0 \\
(0.0 \%)\end{array}$ \\
\hline I am able to budget for electricity in advance & $\begin{array}{l}22 \\
(26.2 \%)\end{array}$ & $\begin{array}{l}36 \\
(42.9 \%)\end{array}$ & $\begin{array}{l}17 \\
(20.2 \%)\end{array}$ & $\begin{array}{l}9 \\
(10.7 \%)\end{array}$ & $\begin{array}{l}0 \\
(0.0 \%)\end{array}$ \\
\hline
\end{tabular}


The influence of the prepaid meter on the success of slum electrification was analyzed on the table 4.10 where $66.7 \%$ of the respondents agreed that prepaid meters had impacted easy monitoring of the number of power units bought, $13.1 \%$ of them disagreed and $20.2 \%$ of the respondents however were not sure, $(58.4 \%)$ of the respondents agreed that prepaid meters had improve power reliability, $16.7 \%, 23.8 \%$ were undecided and $17.9 \%$ disagreed. $72.7 \%$ of the respondents agreed that prepaid meters had enabled them to control electricity consumption, $7.2 \%$ rejected the prompt while $20.2 \%$ were uncertain.

$65.5 \%$ agreed to have decreased tenant-landlord disputes, $21.4 \%$ were undecided and $13.1 \%$ disagreed. The numbers that agreed that there were reduced KPLC employees' interruptions in their premises were $64.3 \%$, $27.0 \%$ disagreed and $25 \%$ of the respondents were undecided on the matter. $71.5 \%$ of the respondents agreed 1.25 were undecided and $2.4 \%$ disagreed that there were reduced frequent complaints to KPLC offices. On the other hand, $68.1 \%$ of the respondents agreed that they were able to budget for electricity in advance, $20.2 \%$ were not sure while $10.7 \%$ disagreed.

Table 4: Means and Standard Deviations of Pre Paid Meters

\begin{tabular}{|c|c|c|c|c|}
\hline & Min & Max & Mean & Std. Dev. \\
\hline Easy monitoring of the no number of power units bought & 1 & 5 & 3.77 & 0.99 \\
\hline Improved power reliability & 1 & 5 & 3.56 & 1.00 \\
\hline Has enabled me to control electricity consumption according to my financial status & 1 & 5 & 4.06 & 0.99 \\
\hline Has decreased tenant-landlord dispute & 2 & 5 & 3.82 & 1.01 \\
\hline Reduced interruptions of KPLC employees in the premises & 2 & 5 & 3.85 & 0.99 \\
\hline Reduced frequent complains to KPLC offices & 1 & 5 & 3.87 & 0.89 \\
\hline I am able to budget for electricity in advance & 2 & 5 & 3.85 & 0.94 \\
\hline
\end{tabular}

In order to gain further understanding of the influence of the prepaid meters on the success of the slum electrification process, the means and standard deviations were calculated as per the table 4.10 and were. 3.77, $3.56,4.06,3.82,3.85,3.87$, and 3.85 respectively and $0.99,1.00,0.99,1.01,0.99,0.89$, and 0.94 respectively. Analyzing the means the respondents on average tended to agree with the prepaid metrics having an influence on the success of slum electrification aspects. On the other hand, the standard deviations showed that there was lack of consensus on the aspects of improved power reliability and decreased tenant-landlord dispute due to standard deviation of above 1.0 .

\section{Slum Electrification}

Table 5: Frequency Distribution of Slum Electrification

\begin{tabular}{|l|l|l|l|l|l|}
\hline & $\begin{array}{l}\text { SA } \\
\text { Freq. } \\
(\boldsymbol{\%})\end{array}$ & $\begin{array}{l}\text { A } \\
\text { Freq. } \\
(\boldsymbol{\%})\end{array}$ & $\begin{array}{l}\text { Ureq. } \\
(\boldsymbol{\%})\end{array}$ & $\begin{array}{l}\text { D } \\
\text { Freq. } \\
(\boldsymbol{\%})\end{array}$ & $\begin{array}{l}\text { SD } \\
\text { Freq. } \\
(\boldsymbol{\%})\end{array}$ \\
\hline Has resulted to Legal slum electricity connections & 23 & 34 & 14 & 13 & 0 \\
& $(27.4 \%)$ & $(40.5 \%)$ & $(16.7 \%)$ & $(15.5 \%)$ & $\begin{array}{l}(0.0 \%) \\
\end{array}$ \\
\hline Flexible power consumption & 17 & 36 & 18 & 13 & 0 \\
& $(20.2 \%)$ & $(42.9 \%)$ & $(21.4 \%)$ & $(15.5 \%)$ & $(0.0 \%)$ \\
\hline Brought safe electricity to slum & 32 & 29 & 17 & 5 & 1 \\
& $(38.1 \%)$ & $(34.5 \%)$ & $(20.2 \%)$ & $(6.0 \%)$ & $(1.2 \%)$ \\
\hline Equitable distribution of electric power in slums & 21 & 45 & 12 & 6 & 0 \\
& $(25.0 \%)$ & $(53.6 \%)$ & $(14.3 \%)$ & $(7.1 \%)$ & $(0.0 \%)$ \\
\hline Improved electric power reliability & 23 & 43 & 10 & 8 & 0 \\
& $(27.3 \%)$ & $(51.2 \%)$ & $(11.9 \%)$ & $(9.5 \%)$ & $(0.0 \%)$ \\
\hline
\end{tabular}

The slum electrification was examined as shown on the table 5. As per the table up to $67.9 \%$ of the respondents believe that diverse interventions on slum electrification have resulted in legal slum electricity connections, while $15.5 \%$ disagreed and $16.7 \%$ were unsure. On the other hand, $63.1 \%$ of the respondents agreed that interventions in slum electrification led to flexible power consumption, $15.5 \%$ of them disagreed and $21.4 \%$ were uncertain, Slum intervention strategies was not appreciated by $7.2 \%$ who disagree that it had brought safety to the slums, $72.6 \%$ of the respondents however agreed while $20.2 \%$ were uncertain. More than a half mark $(78.6 \%)$ of the respondents agreed that slum electrification had brought about equitable distribution of electric power in slums, $7.1 \%$ of them disagreed. $14.3 \%$ of the respondents were undecided. In the context of the improved power reliability as a result of slum electrification, $78.5 \%$ agreed, $9.5 \%$, disagreed while $11.9 \%$ were uncertain.

Table 6: Means and Standard Deviations of Slum Electrification

\begin{tabular}{|l|l|l|l|l|}
\hline & Min & Max & Mean & Std. Dev. \\
\hline Has resulted to Legal slum electricity connections & 2.00 & 5.00 & 3.79 & 1.01 \\
\hline Flexible power consumption & 2.00 & 5.00 & 3.67 & 0.97 \\
\hline Brought safe electricity to slum & 1.00 & 5.00 & 4.02 & 0.96 \\
\hline Equitable distribution of electric power in slums & 2.00 & 5.00 & 3.96 & 0.82 \\
\hline Improved electric power reliability & 2.00 & 5.00 & 3.96 & 0.81 \\
\hline
\end{tabular}


In order to gain an in-depth understanding of the slum electrification, the means and standard deviations of the slum electrification were calculated. The means were 3.79, 3.67, 4.02, 3.96 and 3.96 respectively. On the other hand, the standard deviations of were $1.01,0.97,0.96,0.82$ and 0.81 respectively.

\section{Inferential Statistics}

The inferential statistics were examined through use of the correlation analysis and multiple linear regression.

\section{Correlation Analysis of Subsidized Connection Fee}

The Pearson correlation matrix was used to examine the correlation between subsidized connection fee and slum electrification. The results indicated that there was a moderately strong correlation between subsidized connection fee and slum electrification of $\mathrm{r}(84)=0.579, \mathrm{p}<0.01$.

Table 7: Correlation Analysis of Subsidized Connection
\begin{tabular}{|l|l|}
\hline & Slum Electrification \\
\hline Subsidized Connection Fee & $.579^{* *}$ \\
\hline
\end{tabular}
**. Correlation is significant at the 0.01 level (2-tailed).

The results are consistent with the findings of other scholars. The distribution of electricity whether for social or productive uses is a capital-intensive enterprise, and the cost of providing household connection to electricity services can be quite high (Njoroge, 2015). When connection charges are recovered through onetime, up-front fees for new customers, they can constitute a powerful disincentive to people who wish to obtain electricity, no matter how much they might desire the service(Kristiansen, 2015). High electricity connection prices can discourage low-income households that may be able to afford the monthly bills. This is because, in practice, high bills are not such an obstacle, because the cost of alternatives generally used, such as kerosene oil, candles and batteries, are comparable to most grid-supplied electricity tariffs for small consumers. The main obstacle is the high up-front charges the consumer has to pay for a grid connection. These include the cost of house wiring and the connection charge payable to the utility(Kawa, 2013).

\section{Table 8: Pre Paid Metering}

The Pearson correlation matrix was used to examine the correlation between pre paid metering and slum electrification. The results indicated that there was a weak correlation between pre paid metering and slum electrification of $r(84)=0.499, p<0.01$ as illustrated in table 4.15 .

\section{Correlation Analysis of Subsidized Connection}

\begin{tabular}{ll}
\hline Prepaid meter & $\begin{array}{l}\text { Slum Electrification } \\
.499^{* *}\end{array}$ \\
\hline$* *$ Correlation is significant at the 0.01 level (2-tailed). &
\end{tabular}

The significance of the prepayment system on the subsidized connection was also noted in diverse countries across the world. For example, Lange (2008) state results of a survey conducted among local electricity users indicated that prepaid meters lead to increase in welfare. They also indicate that the advantages of the system are linked to the reduction of arrears in accounts receivables and of operational and financial costs on the part of the service provider and to a better allocation of resources for the user(Kitungu, 2014). Scott (2014)did a cost benefit analysis of prepaid meters in South Africa and found it possible to identify the change in aggregate welfare resulting from the adoption of the prepayment system as well as in each of the groups concerned.

\section{Conclusions}

The study concluded that the subsidized connection fee had statistically significant influence on the successful implementation of slum electrification. The statistical significance of the subsidized connection fee with the slum electrification lies with the poverty levels that is prevalent in slum areas. Most slum dwellers lack the financial capacity to pay the electricity connection at the market rate and therefore the subsidization of the connection fee leads to an increase in customers seeking electricity connection.

The study found that the pre paid metering had no significant influence on the successful implementation of slum electrification. One of the reasons that attributed to this was the fact that a majority of the slum dwellers were not in a position to pay up the electricity token after the initial tokens had been used as well as challenges with the KPLC team in ensuring that all the pre paid meters are vending. 


\section{References}

[1]. Bystedt, C. (2011). Public Space Planning as a Catalyst for Dweller Initiated Slum Upgrading: Ahmedabad , India. Journal of Business and Management, 2(3), 15-23.

[2]. Cheseto, M. (2013). Challenges in Planning for Electricity Infrastracture in Informal Settlements; Case of Kosovo Village, Mathare Valley Nairobi. Journal of Management Research, 2(1), 36-42.

[3]. Kawa, F. (2013). Automation and Operational Performance in Hydro Electric Power Generation Sector. International Multidisciplinary Journal, 2(3), 25-30.

[4]. Kitungu, A. K. (2014). Supply Chain Factors and Delivery of Power Generation Projects at the Kenya Electricity Generating Company Limited. Journal of Sustainable Development in Africa, 2(3), 29-35.

[5]. Kombo, D. K., \& Tromp, D. L. A. (2009). Proposal and Thesis Writing: An Introduction. Nairobi, Kenya: Paulines Publications Africa, Don Bosco Printing Press.

[6]. Kristiansen, T. (2015). Risk Management in Electricity Markets Emphasizing Transmission Congestion. Journal of Business and Management, 2(3), 25-29.

[7]. Lange, D. (2008). The impact of increased electricity prices on consumer demand. International Journal of Adnaced Research, 2(3), $65-72$.

[8]. Njoroge, J. (2015). Influence of the Kenya Power Slum Electrification Use in Slums in Kenya; The Case of Munyaka Informal Settlement, Uasin Gishu County. Journal of Business and Management, 2(3), 35-30.

[9]. Njoroge, J. (2015). Influence of the Kenya Power Slum Electrification Use in Slums in Kenya; The Case of Munyaka Informal Settlement, Uasin Gishu County. Journal of Business and Management, 2(3), 35-30.

[10]. Saibu, O. M. (2016). Macroeconomic Determinants of Renewable Electricity Technology Adoption in Nigeria, 16(1), 65-83.

[11]. Scott, C. (2014). Electrifying the Bottom of the Pyramid : Improving Access in Slums. Journal of Business and Management, 2(3), 45-50.

[12]. Scott, C. (2014). Electrifying the Bottom of the Pyramid: Improving Access in Slums. Journal of Business and Management, 2(3), 45-50.

[13]. Wafula, S. (2012). Mapping the Physical Constraints to Food Safety in Nairobi's Informal Settlements: Case Study of Mathare. Journal of International Development, 2(2), 45-50. 